ENVIRONMENTAL

RESTORATION PROGRAM

\section{Geology Summary of Waste Area Grouping 5 at Oak Ridge National Laboratory, Oak Ridge, Tennessee}




\section{Author Afriliations}

Julia E. Anderson is a junior at the University of St. Petersburg in Russia. She participated in a three-month environmental internship program for professional development and on-the-job training in environmental restoration activities. Julia is the first participant in the International Environmental Student Intern Program, a pilot effort managed by the Office of International Programs in Lockheed Martin's Environmental Management and Enrichment Facilities Organization. The DOE Office of Environmental Management has a bilateral agreement with the Russian Federation Ministry of Atomic Energy (MINATOM) to conduct joint environmental research and development activities.

This report was prepared under the direction of Julia's research advisor and mentor, RaNaye B. Dreier of the Environmental Sciences Division, Oak Ridge National Laboratory. Robert A. Kite, Energy Systems Environmental Restoration Program, served as her host and sponsor. Tom Mayfield, Director, and Adelle Cooter, Program Manager, of the Office of International Programs served as her coordinators and liaisons for the pilot training activity.

This report has been reproduced directly from the best available copy.

Available to DOE and DOE contractors from the Office of Scientific andTechnical Information, P.O. Box 62, Oak Ridge, TN 37831; prices available from 423-576-8401 (fax 423-576-2865).

Available to the public from the National Technical Information Service, U.S. Department of Commerce, 5285 Port Royal Rd., Springfield, VA 22161. 
Energy Systems Environmental Restoration Program

\author{
Geology Summary \\ of Waste Area Grouping 5 \\ at Oak Ridge National Laboratory, \\ Oak Ridge, Tennessee
}

\author{
J. E. Anderson
}

Date Issued-August 1996

\author{
Prepared by \\ Environmental Sciences Division \\ Oak Ridge National Laboratory \\ Prepared for the \\ U.S. Department of Energy \\ Office of Environmental Management \\ under budget and reporting code EW 20 \\ Environmental Management Activities at the \\ OAK RIDGE NATIONAL LABORATORY \\ Oak Ridge, Tennessee 37831-6285 \\ managed by \\ LOCKHEED MARTIN ENERGY SYSTEMS, INC. \\ for the \\ U.S. DEPARTMENT OF ENERGY \\ under contract DE-AC05-84OR21400
}




\section{CONTENTS}

FIGURES $\ldots \ldots \ldots \ldots \ldots \ldots \ldots \ldots \ldots \ldots \ldots \ldots \ldots \ldots \ldots \ldots \ldots \ldots \ldots \ldots, \quad v$

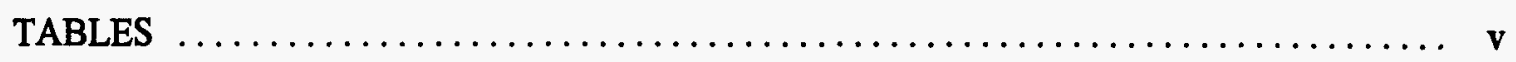

ABBREVIATIONS/DEFINITIONS $\ldots \ldots \ldots \ldots \ldots \ldots \ldots \ldots \ldots \ldots \ldots \ldots \ldots \ldots \ldots \ldots \ldots$ vii

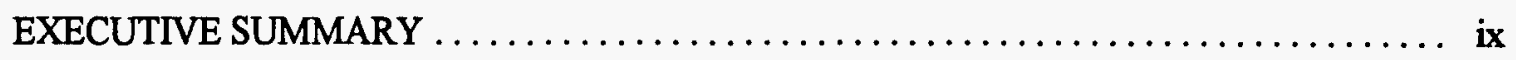

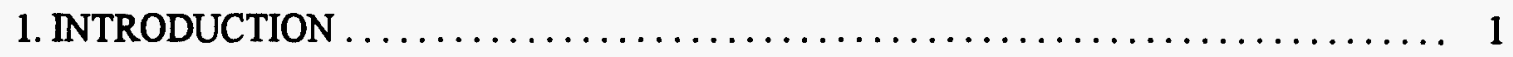

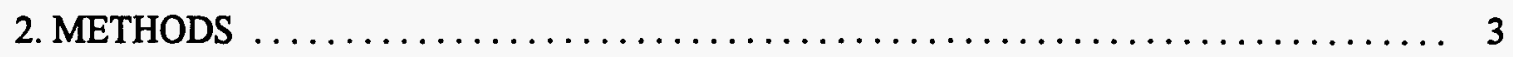

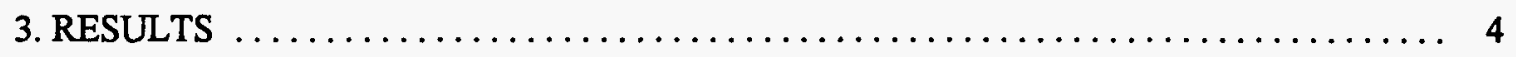

3.1 STRATIGRAPHIC CORRELATION DIAGRAMS $\ldots \ldots \ldots \ldots \ldots \ldots \ldots \ldots, 4$

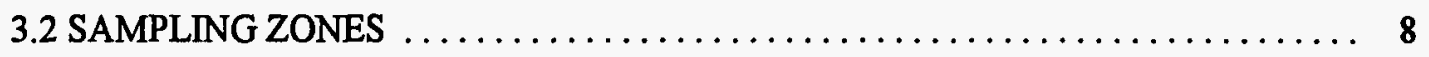

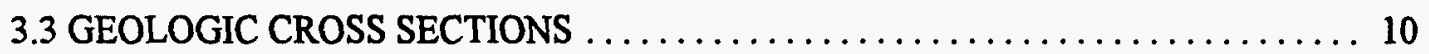

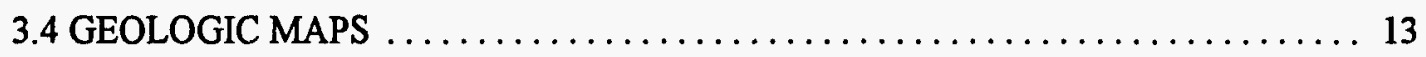

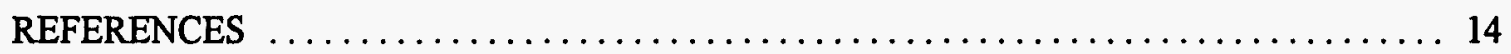




\section{FIGURES}

1. Westbay Well location map by P. Lemiszki (Hatcher et al., 1992) ............ 2

2. WAG 5 stratigraphic correlation (BNI/Smith version) $\ldots \ldots \ldots \ldots \ldots \ldots \ldots \ldots \ldots$

3. WAG 5 stratigraphic correlation (new version) $\ldots \ldots \ldots \ldots \ldots \ldots \ldots \ldots \ldots \ldots$

4. Strike-perpendicular geologic cross section in WAG $5 . \ldots \ldots \ldots \ldots \ldots \ldots \ldots \ldots \ldots$

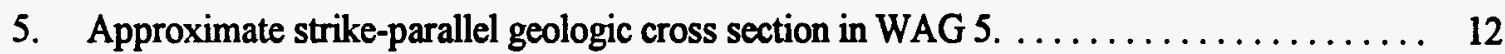

\section{TABLES}

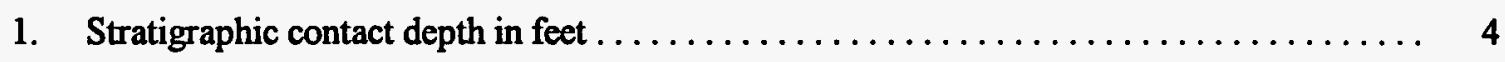

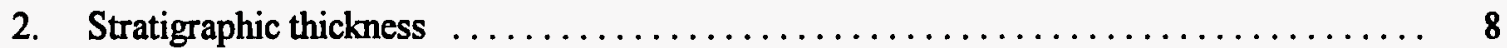

3. Sampling zone stratigraphic correlation $\ldots \ldots \ldots \ldots \ldots \ldots \ldots \ldots \ldots \ldots \ldots \ldots$

4. Sampling zones depth correlation $\ldots \ldots \ldots \ldots \ldots \ldots \ldots \ldots \ldots \ldots \ldots \ldots \ldots \ldots \ldots \ldots \ldots \ldots \ldots$ 


\section{ABBREVIATIONS/DEFINITIONS}

BNI

$\mathrm{Cm}$

$\mathrm{Cn}$

cps

Cpv

$\mathrm{Crg}$

$\mathrm{Crt}$

multiport wells

ORR

WAG

Waste Area Grouping
Bechtel National, Inc.

Maryville Limestone

Nolichucky Shale

counts per second

Pumpkin Valley Shale

Rogersville Shale

Rutledge Limestone

Multiport wells are designed to allow multi-level sampling and monitoring. Any number of monitoring zones can be installed in a single borehole.

Oak Ridge Reservation

Waste Area Grouping

All known active and inactive waste areas, contaminated facilities, and potential sources of continuing release to the environment at Oak Ridge National Laboratory have been categorized into Waste Area Groupings, each of which contains sites within geographically and/or hydrologically defined units. The WAG concept was developed to subdivide the remedial action sites into manageable units that could be handled separately. 


\section{EXECUTIVE SUMMARY}

During FY 1994, three multiport wells were installed in Waste Area Grouping (WAG) 5 . The wells were instrumented with Westbay multiport systems. The purpose of the wells is (1) to characterize different flow systems and (2) to monitor for contaminants. The geology of the individual boreholes (WAG 5-12, WAG 5-13, WAG 5-14) is documented in Bechtel National, Inc., (BNI) et al. (1994). BNI et al. (1994) does not explicitly show geologic relationships between these boreholes or integrate this information into the geology of WAG 5. The purpose of this report is to document and present a summary of the distribution of geologic formations in WAG 5. This information is presented in several ways: (1) stratigraphic correlation diagrams based on the natural gamma ray log, (2) geologic cross sections, and (3) a geologic map. This work provides a reference frame for interpreting flow, water, and contaminant chemistry data from multiport wells. 


\section{INTRODUCTION}

During FY 1994, three multiport wells were installed in Waste Area Grouping (WAG) 5. Well locations are shown in Fig. 1. The wells were instrumented with Westbay multiport systems. The purpose of the wells is (1) to characterize different flow systems and (2) to monitor for contaminants. The geology of the individual boreholes (WAG 5-12, WAG 5-13, WAG 5-14) is documented in Bechtel National, Inc., (BNI) et al. (1994). BNI et al. (1994) does not explicitly show geologic relationships between these boreholes or integrate this information into the geology of WAG 5. The purpose of this report is to document and present a summary of the distribution of geologic formations in WAG 5. This work provides a reference frame for interpreting flow, water, and contaminant chemistry data from multiport wells.

General geologic information about stratigraphic units in WAG 5 can be found in Hatcher et al. (1992). Geologic formations in WAG 5 consist of Cambrian-age Conasauga Group and include Pumpkin Valley Shale (Cpv), Rutledge Limestone (Crt), Rogersville Shale (Crg), Maryville Limestone (Cm) and Nolichucky Shale (Cn). Construction and installation information for multiport wells is presented in BNI et al. (1994). Geophysical logging was done for each well and the cores were described. Based on geophysical logs, contacts between stratigraphic formations were determined and multiple sampling zones were chosen for each well (BNI, 1994). 


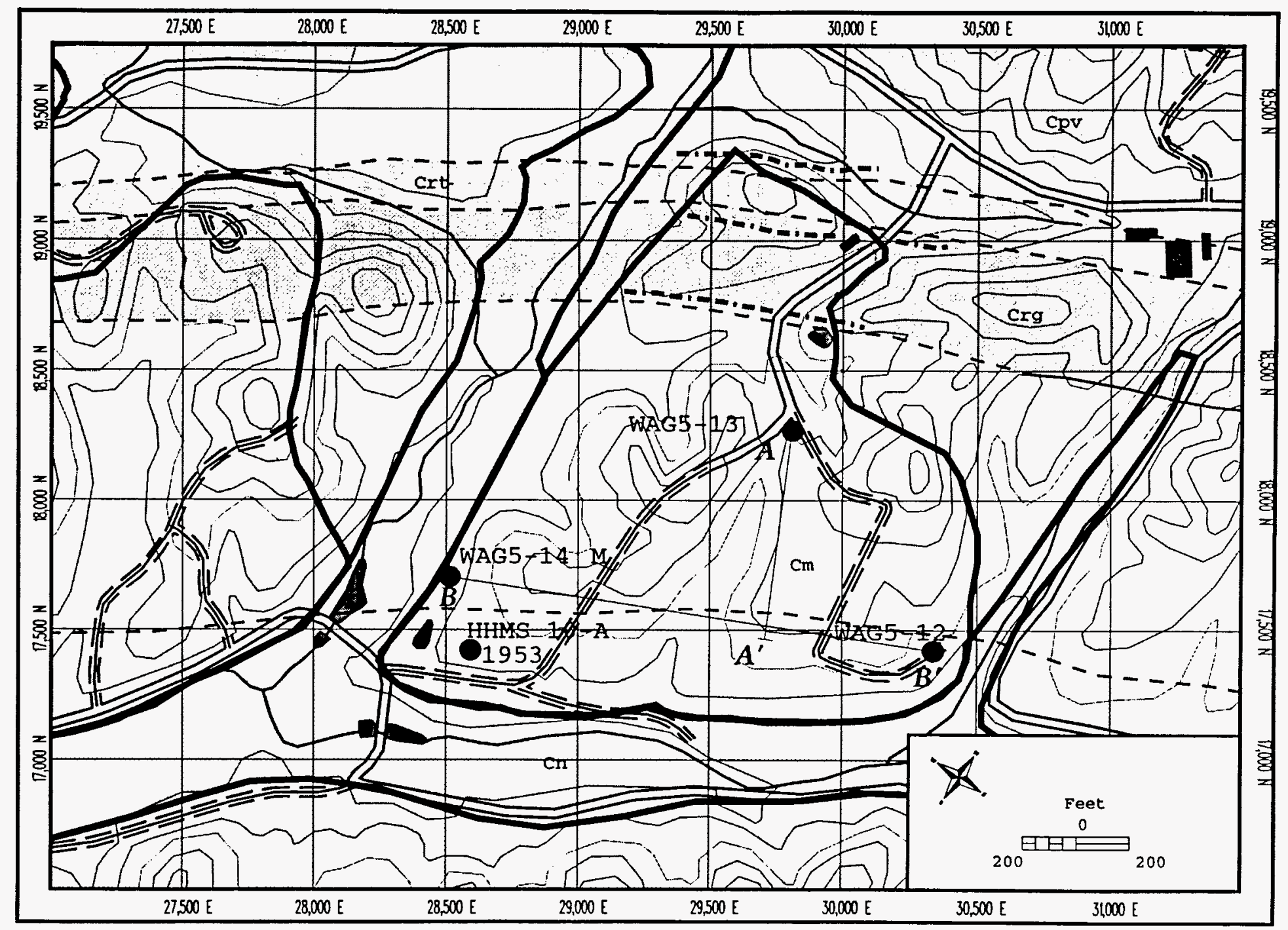

$N$

Fig. 1. Westbay Well location map by Lemiszki (Hatcher et al., 1992). Original contacts are shown by dashed lines. Our contacts are shown by the dash-dot lines for WAG 5 only. AA' and BB' $=$ lines of the cross section. 


\section{METHODS}

Geologic information in this report is presented in several ways:

1. Stratigraphic correlation diagrams based on the natural gamma ray log. A natural gamma log easily distinguishes individual beds of shale and limestone. In addition, geophysical descriptions of geology on the Oak Ridge Reservation (ORR) are already available (Hatcher et al., 1992), so we can compare geophysical logs from WAG 5 wells with those presented in that report. To make decisions and distinguish the beds, we (1) observe baseline trends on gamma ray log diagrams (i.e., we observe and contrast both gradual and abrupt shifts in the average gamma ray value) and (2) compare the values of the gamma logs [counts per second (cps)]. The same formations should show similar values in wells that are similarly constructed.

2. Geologic cross sections. To construct geologic cross sections, we first determined strike and dip of the beds in WAG 5. For that purpose, we used the standard three point problem solution, which determines dip and strike from three points each with different elevations (Ragan, 1973). Then we constructed a strike-perpendicular cross section and projected data onto the line of section.

3. Geologic maps. A geologic map of WAG 5 is included in the ORR map prepared by Peter Lemiszki and is presented in Hatcher et al. (1992). This map is based on surface geologic data. We tried to integrate surface and subsurface geologic data so that they are internally consistent. 


\section{RESULTS}

\subsection{STRATIGRAPHIC CORRELATION DIAGRAMS}

There are two versions of the stratigraphic correlation of WAG 5 geologic units. One of them is presented in BNI et al. (1994) and is based on work done by J. Smith in 1994. We suggest another version which is presented in this work. The BNI/Smith version is shown on Fig. 2. Figure 3 shows our version. The major contacts according to our version are given in Table 1.

\section{Table 1. Stratigraphic contact depth in feet*}

\begin{tabular}{l|ccc|}
\cline { 2 - 4 } & WAG5-12 & WAG5-13 & WAG5-14 \\
\cline { 2 - 4 } $\begin{array}{l}\text { Top of } \mathrm{Cm} \\
\text { Top of } \mathrm{Crg}\end{array}$ & 265 & $\mathrm{NA}$ & 185 \\
Top of Crt & 380 & 184 & 326 \\
Top of Cpv & 470 & 310 & 451 \\
$\mathrm{NA}$ & 484 & $\mathrm{NA}$ \\
\hline
\end{tabular}

*Depth is given in feet below ground surface, measured along the borehole.

Symbols: Cm (lower) - lower Maryville Limestone, $\mathrm{Crg}$ Rogersville Shale, $\mathrm{Crt}$ - Rutledge Limestone, Cpv - Pumpkin Valley Shale.

NA = Not available. 


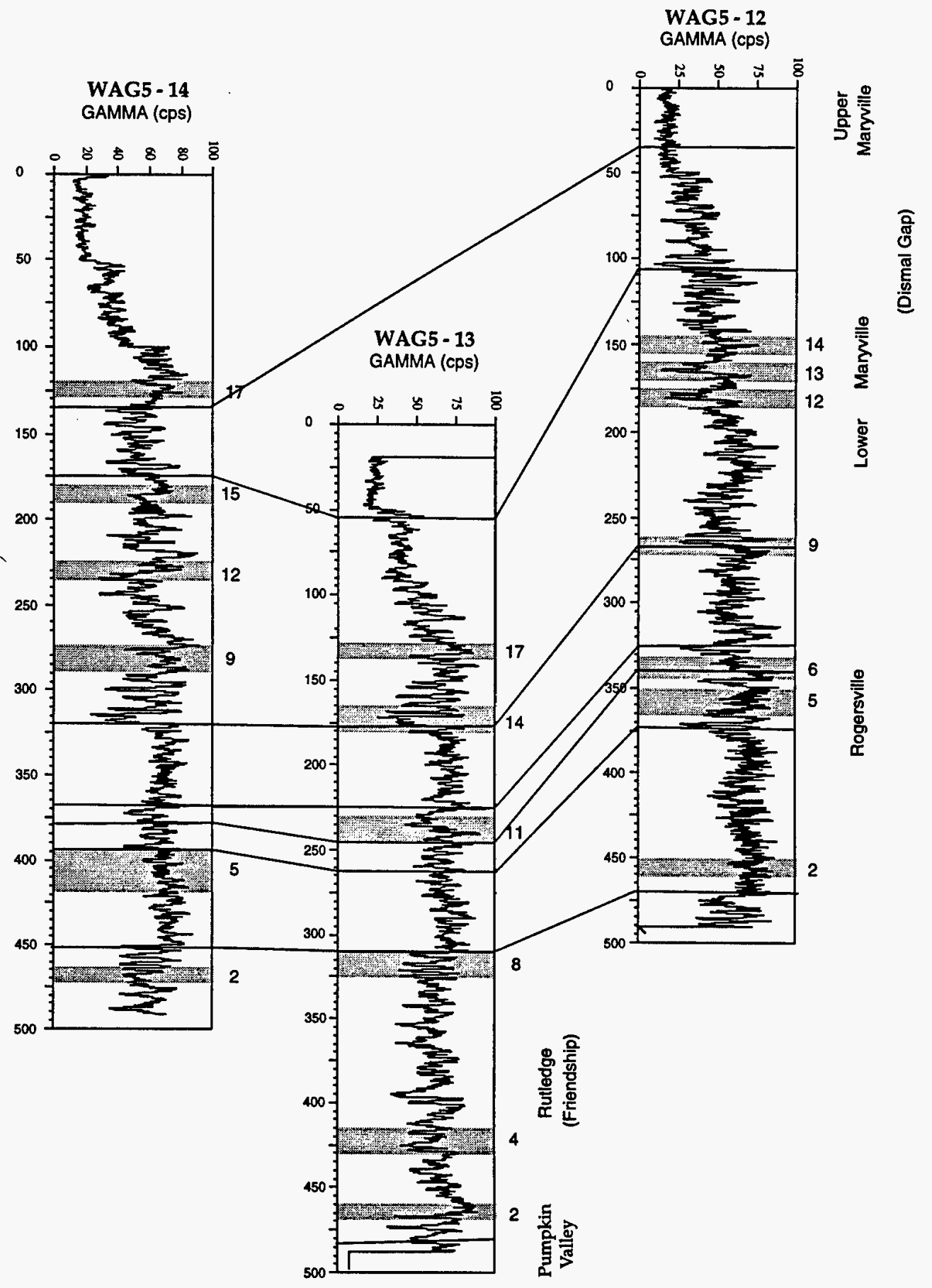

Fig. 2. WAG 5 stratigraphic correlation (BNI/Smith version). Sampling zones (by BNI, 1994) are illustrated by gray bars. 


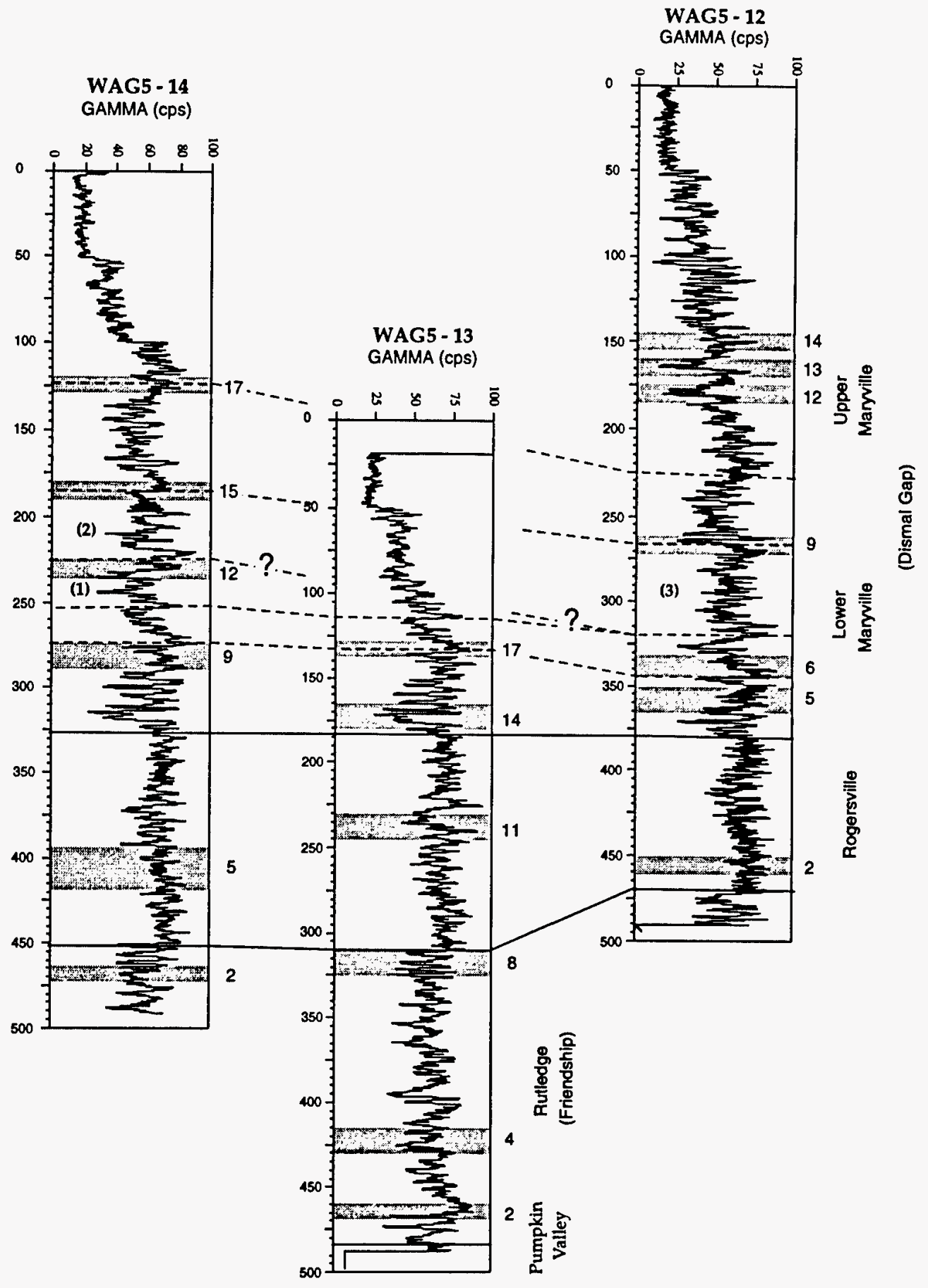

Fig. 3. WAG 5 stratigraphic correlation (new version). Sampling zones are shown by gray bars. 
The primary difference between the two versions is in the thickness of the Rogersville Shale in WAG 5-12. The Rogersville Shale is easily recognized by a stable baseline. The lower contact with the Rutledge Limestone can be seen easily from the natural gamma log diagrams for each well. It is the same for both interpretations. But the upper contact between the Rogersville Shale and the Maryville Limestone for WAG 5-12 is different in the two versions: it is placed at the depth of $267 \mathrm{ft}$ in the old version (Fig. 1) and at $380 \mathrm{ft}$ in the new one (Fig. 2).

The reasons why we trust our correlation more than the previous one are as follows:

1. The old one does not match the type description. The lithology between 340 and $267 \mathrm{ft}$ depth at the top of the formation is a gray to greenish gray shale. The type description of the Rogersville Shale shows a maroon shale for this interval (Table 5 listed in BNI et al., 1994).

2. The Rogersville Shale in the original version (Fig. 1) is thicker than any other Rogersville Shale observed in Melton Valley. Thicknesses of geologic units for Melton Valley and Bear Creek Valley (Hatcher et al., 1992) and for WAG 5 (both correlations) are given in Table 2.

3. The Rogersville Shale, according to the original version, contains a relatively large proportion of limestone. This is seen by the baseline shift toward higher cps within the shale bed on the gamma log diagram. Type descriptions of the Rogersville Shale do not include limestone (Hatcher, 1992).

We suggest that the baseline shift and changing baseline above $380 \mathrm{ft}$ corresponds to the Maryville Limestone. The problem of our version is that all beds become thinner in the well WAG 5-12, but we still trust it more than the original version.

The bottom of the Rutledge Limestone (top of the Pumpkin Valley Shale) is observed only in WAG 5-13. It is the same for both versions. To check this contact, the natural gamma logs were compared with those of Bear Creek Valley and Melton Valley (Hatcher et al., 1992).

Some of the contacts on Fig. 3 are shown with a dashed line. These are informal contacts that occur within a formation, and they are not so certain as contacts between formations. Nevertheless, we feel confident with this correlation on a local scale. The informal contact between lower Maryville Limestone and upper Maryville Limestone is determined only for wells WAG 5-12 and WAG 5-14. For WAG 5-13, it is not available because the surface casing extends past the contact. 
Table 2. Stratigraphic thickness*

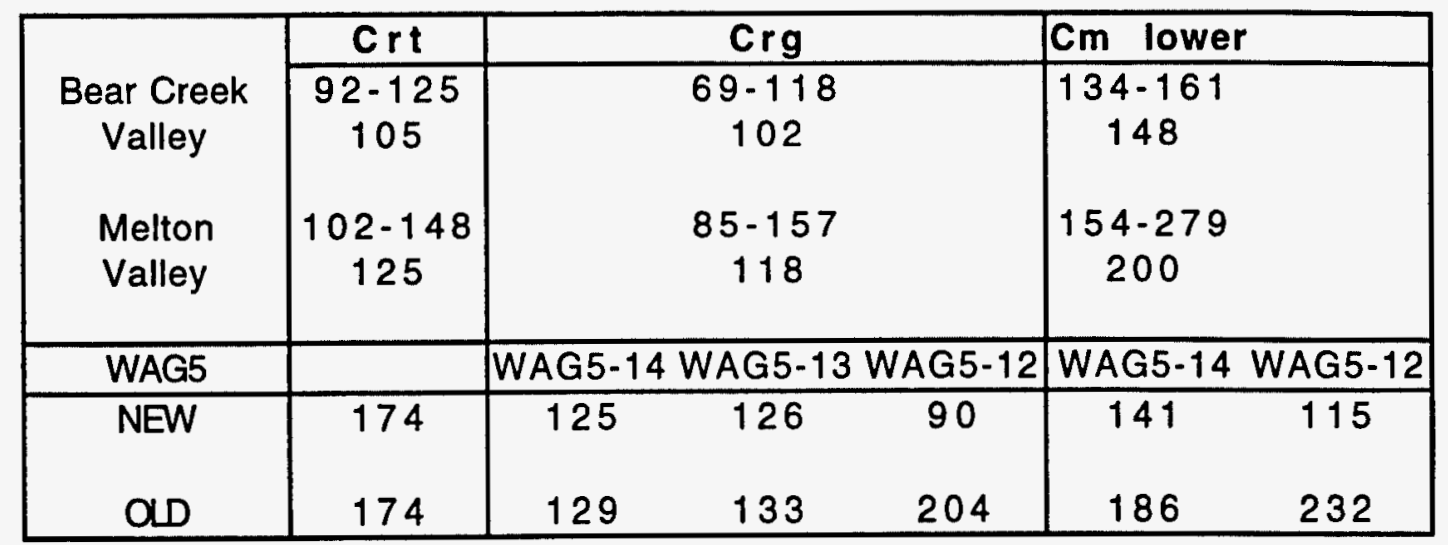

*Thickness of geologic units is given in feet. Thicknesses of units in Bear Creek Valley and Melton Valley are taken from Hatcher et al. (1992). Thickness is given as a range $(\mathrm{X}-\mathrm{X})$ and as an average. $\mathrm{NEW}=$ thickness according to new correlation (given in this report); OLD = thickness according to old correlation (BNI/Smith).

The correlation figure (Fig. 3) shows that the bed thickness is relatively constant from WAG5-14 to WAG5-13 but is thinner in WAG5-12. In addition, as shown by the dashed lines with "?" question marks, the package (1) possibly is structurally duplicated in WAG5-14. Alternatively it may just show similar thinning as in surrounding units.

\subsection{SAMPLING ZONES}

Sampling zones for WAG 5 multiport wells are presented in BNI et al. (1994) and are illustrated in Figs. 2 and 3 by a gray bar. Stratigraphic correlation of sampling zones in wells WAG5-12, WAG5-13, WAG5-14 is given in Table 3. In addition, sampling zones that occur at a similar depth (within $25 \mathrm{ft}$ ) are shown in Table 4. These tables help to put hydrologic data (such as water chemistry or fluid pressure) into a geologic context, particularty bocause the zones were chosen from hydrogeologic data. 
Table 3. Sampling zone stratigraphic correlation*

\begin{tabular}{|c|c|c|c|}
\hline $\begin{array}{c}\text { Stratigraphic } \\
\text { Unit }\end{array}$ & $\begin{array}{c}\text { WAG5-12 } \\
\text { Zone } \\
\end{array}$ & $\begin{array}{c}\text { WAG5-13 } \\
\text { Zone }\end{array}$ & $\begin{array}{c}\text { WAG5-14 } \\
\text { Zone }\end{array}$ \\
\hline $\begin{array}{c}\text { Upper } \\
\text { Maryville }\end{array}$ & $\begin{array}{l}14 \\
13 \\
12\end{array}$ & & 17 \\
\hline $\begin{array}{c}\text { Lower } \\
\text { Maryville }\end{array}$ & $\begin{array}{c}9 \\
6 \\
5 \\
5\end{array}$ & $\begin{array}{c}17 \\
17 \\
14\end{array}$ & $\begin{array}{l}17 \\
15 \\
12 \\
\\
9\end{array}$ \\
\hline Rogersville & 2 & 11 & 5 \\
\hline Rutledge & & $\begin{array}{l}8 \\
4 \\
2\end{array}$ & 2 \\
\hline
\end{tabular}

* Sampling zones are numbered consecutively from the base of the well. Sampling zones within the same stratigraphic unit are shown by gray bars.

Table 4. Sampling zones depth correlation*

\begin{tabular}{|c|c|c|c|}
\hline $\begin{array}{c}\text { Depth Range } \\
(f t)\end{array}$ & $\begin{array}{l}\text { WAG5-12 } \\
\text { Zone }\end{array}$ & $\begin{array}{l}\text { WAG5-13 } \\
\text { Zone }\end{array}$ & $\begin{array}{l}\text { WAG5-14 } \\
\text { Zone }\end{array}$ \\
\hline $124-135$ & & \multicolumn{2}{|r|}{17} \\
\hline $135-150$ & 14 & \multirow{2}{*}{\multicolumn{2}{|c|}{17}} \\
\hline 165 & 13 & & \\
\hline $173-185$ & 3re & \multicolumn{2}{|c|}{$14=15$} \\
\hline $230-238$ & & \multirow[t]{2}{*}{11} & 12 \\
\hline $265-282$ & 9 & & \multirow[t]{2}{*}{9} \\
\hline 317.338 & $3-26$ & 80 & \\
\hline 360 & 5 & \multirow[b]{2}{*}{4} & \\
\hline $407-423$ & & & 5 \\
\hline 4564469 & -772 & 2 & 2 \\
\hline
\end{tabular}

*Depth is given in feet below surface. Zones that occur within a 25-ft range are shown by gray bars. 


\subsection{GEOLOGIC CROSS SECTIONS}

Geologic strike and dip were determined from three-point problem analysis. The contact Rogersville Shale-Maryville Limestone as observed in the three multiport wells in WAG 5 was accepted as a marker. For solving the problem, we generated an EXCEL spreadsheet and used the method described in Ragan (1973). Bed strike is approximately 95 degrees east with a dip 14 degrees to the south. But strike and dip can vary slightly for other marker beds because bed thickness varies between boreholes.

A strike perpendicular cross section A-A' (Fig. 4) was constructed through the well WAG 5-13. The line of section is shown in Fig. 1. Data from wells WAG 5-12 and WAG 5-14 were projected along strike into the section. Strata observed in wells WAG 5-13 and WAG 5-14 show a relatively constant thickness. In contrast, as discussed earlier, strata observed in well WAG 5-12 show substantial thinning, resulting in change in the value of dip at different formation contacts. Therefore, change between WAG 5-14 and WAG 5-12 shows geologic changes along strike. This cross section illustrates the problem of thickness change between WAG 5-14 and WAG 5-12 beds. As a result, the portion of the cross-section between WAG 5-12 and WAG 5-14 probably is not representative of the geology along the line of section. Based on it we can only say that a lot of changes along strike take place.

\section{Implications:}

1. Strike and dip calculations can only be approximate and strike may vary 5 to 10 degrees.

2. Data from WAG 5-12 should not be projected onto strike perpendicular cross-section.

Therefore, we constructed a second strike parallel cross section (Fig. 5) to illustrate thickness changes at a 1-to-1 scale. This cross section shows bed thinning from WAG 5-14 (grid-west) to WAG 5-12 (grid-east). Bed thinning in WAG 5-12 remains a problem in interpretation that may not be resolved. The suggestion is that the thickness change is an original sedimentary feature. Probably it is caused by the surface relief during the deposition. But for beds (1) and (2) within lower Maryville Limestone, thinning may be the result of subhorizontal thrust fault, which cuts through the well WAG 5-14 at an elevation of about $547 \mathrm{ft}$ and through WAG 5-12 at an elevation of about $476 \mathrm{ft}$. In that case, we can suggest that section (1) has been repeated and (2) is the same bed as (1) (Figs. 3 and 5). Based on the gamma log diagrams (Fig. 3), this is the most likely location of a fault. Alternatively, the strata between a depth of 185 and $255 \mathrm{ft}$ in WAG 5-14 corresponds to bed (3) in WAG 5-12 (Fig. 3). The relationship between beds (1), (2), and (3) (Figs. 3 and 5) is questionable and needs more study. 


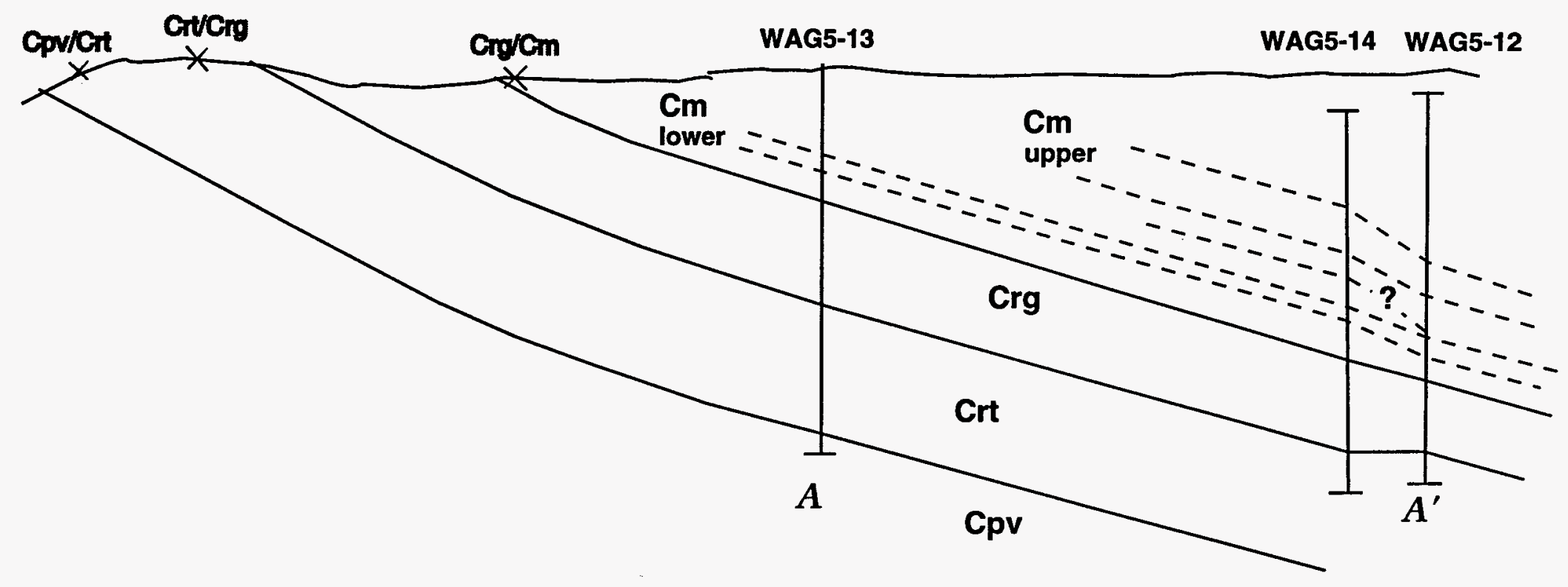

Fig. 4. Strike-perpendicular geologic cross section in WAG 5. Geologic contacts taken from Hatcher et al. (1992) are shown by $X$. 


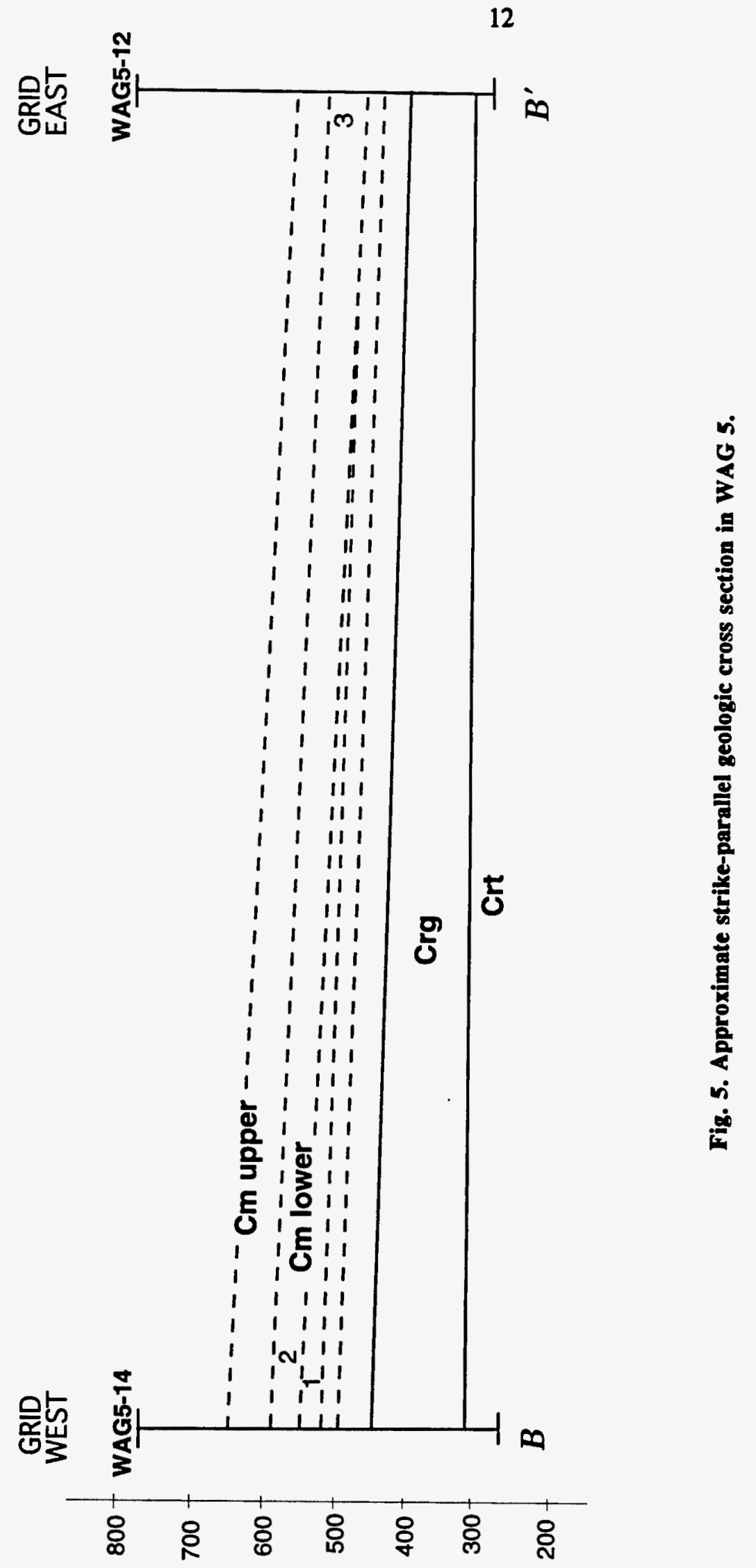




\subsection{GEOLOGIC MAPS}

The geologic map of WAG 5, which is based on data presented in Hatcher et al. (1992), shows the $\mathrm{Cpv}-\mathrm{Crt}$, $\mathrm{Crt}-\mathrm{Crg}$, and $\mathrm{Crg}-\mathrm{Cm}$ surface contacts in the northern part of WAG 5 (Fig. 1). The surface contacts were put on the cross section through wells WAG 5-12, WAG 5-13, and WAG 5-14 (Fig. 1). It shows a slight mismatch between subsurface and surface data. Surface contacts require a Rogersville Shale thickness increase and thickness decrease of the Rutledge Limestone. Because of the fact that (1) such a large increase and decrease requires a complicated geologic history and (2) it is difficult to perform both an increase and decrease in thickness by simply changing the dip, we prefer to interpret the situation the uncomplicated way (i.e., projecting of subsurface data to the surface with a minor change in the value of dip). Therefore, in order to make the thickness constant, the Rutledge Limestone-Rogersville Shale contact was moved about $70 \mathrm{ft}$ south, the Pumpkin Valley Shale-Rutledge Limestone contact was moved about $50 \mathrm{ft}$ north, and the Rogersville Shale-Maryville Limestone contact was moved about $30 \mathrm{ft}$ north. The surface topography supports this interpretation: the hill (Fig. 4) is probably formed by the Rutledge Limestone, which is more resistant than the Rogersville Shale, and decrease of surface elevation corresponds to the Rogersville Shale. 


\section{REFERENCES}

Bechtel National, Inc./CH2M HILL/OGDEN/PEER. 1994. Multizone Well Installation at WAG 5. ORNL RI/FC Project Technical Bulletin 05-TB-033.

Hatcher, R. D., Jr., P. J. Lemiszki, R. B. Dreier, R. H. Ketelle, R. R. Lee, D. A. Lietzke, W. M. McMaster, J. L. Foreman, and S. Y. Lee. 1992. Status Report on the Geology of the Oak Ridge Reservation. ORNL/TM-12074. Oak Ridge National Laboratory, Oak Ridge, Tennessee.

Ragan, Donal M. 1973. Structural Geology. An Introduction to Geometrical Techniques. Second Edition. John Wiley and Sons. New York. 


\section{DISTRIBUTION}

1-5. J. E. Anderson

6. L. V. Asplund

7. A. J. Caldanaro

8-16. A. V. Cooter

17. R. B. Dreier

18. L. K. Hyder

19. P. M. Jardine

20. B. L. Kimmel

21-23. R. A. Kite

24. D. M. Matteo

25. T. L. Mayfield

26. J. F. McCarthy

27. G. R. Moline

28. P. T. Owen

29. P. A. Schrandt

30. M. S. Uziel

31. Central Research Library

32. ER Document Management Center-RC

33-34. Office of Scientific and Technical Information, P.O. Box 62, Oak Ridge, TN 37831 
M98054460

|||||||||||||||||||||||||||||||||||||||||||||-10

Report Number (14) ORNL/ER/MS -- 1

Publ. Date (11) 199608

Sponsor Code (18) DOE IEM , XF

UC Category (19) UC-2000, DOE/ER

19980720104

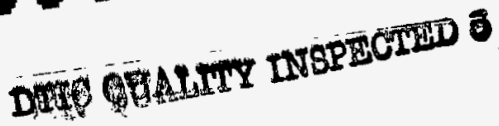

DOE 